\title{
Lived Experience of Academic Librarians of Color
}

\author{
Juleah Swanson, Azusa Tanaka, and Isabel \\ Gonzalez-Smith
}

\begin{abstract}
Lived experience encompasses the perceptions, feelings, and context of an individual's human experience. Researching lived experience can be a way of understanding identity, emotions, perceptions, and contexts to develop a more thoughtful understanding of human experience. This research explores the following questions: what are the lived experiences of people of color who work as academic librarians in the profession; what are the contexts of their experiences; and how do these librarians see themselves? Through qualitative research using a phenomenological approach, this research reveals the complex, nuanced, and varied lived experiences of academic librarians of color navigating a predominantly white profession.
\end{abstract}

\section{Introduction}

Two people sitting at a reference desk, sharing the same moment, sharing the same space, are not sharing the same lived experience. Lived experience can be succinctly stated as "life as we live it," ${ }^{1}$ but lived experience in research encompasses the perceptions, feelings, and context of an experience. ${ }^{2}$ In studying the human experience, lived experience is a methodological concept derived from phenomenology. ${ }^{3}$ The study of phenomenology requires the researcher to understand the world, not as it is observed, but rather as it is experienced. ${ }^{4}$ The application of lived experience research is visible in such disciplines as psychology, sociology, social work, public health, education, and among researchers seeking to understand human experience in a manner that centers and acknowledges every aspect of a subject's life and identity. ${ }^{5}$ Boylorn argues that the utility of lived experience research is that "separate life experiences can resemble and respond to larger public and social themes, creating space for storytelling, interpretation, and meaning-making." 6

Juleah Swanson is Assistant Professor and Head of Acquisition Services at the University of Colorado Boulder; email: juleah.swanson@colorado.edu. Azusa Tanaka is Japanese Studies Librarian at the University of Washington; email: azusat@uw.edu. Isabel Gonzalez-Smith was formerly Undergraduate Experience Librarian at the University of Illinois Chicago. The authors extend their gratitude to the University Library at the University of Illinois Chicago and the Committee on Faculty Benefits, Responsibilities and Research at The Ohio State University Libraries for financial support of this research. The authors would also like to thank Shanika Blanton and Ebony Edwards, Graduate Assistants from the Department of Psychology at the University of Illinois Chicago, for their contributions to this research. (C2018 Juleah Swanson, Azusa Tanaka, and Isabel Gonzalez-Smith, Attribution-NonCommercial (http://creativecommons.org/licenses/ by-nc/4.0/) CC BY-NC 
No prior research has explored the lived experience of academic librarians of color from a phenomenological perspective, including the perceptions, feelings, and contexts of experience. We can apply lived experience research to the study of academic librarians who self-identify as persons of color as a way of understanding the human experience of being a person of color navigating a predominantly white profession. This research explores the following questions: what are the experiences of people of color who work as academic librarians in the profession; what are the contexts of their experiences; and how do these librarians see themselves?

\section{Literature Review}

Research outside library and information science that has explored lived experience is extensive. We provide only a small sampling of research on lived experience to highlight some of the value and implications of such research. One study explores the lived experience of LGBT Christians, examining participants' construction of identity and their experiences with counseling, health, and spiritual professionals to develop greater understanding among social workers or counselors who may serve these clients. ${ }^{7}$ Another study examines the lived experience of those with severe mental illness, revealing the ways mental illness influences everyday activity and how mental illness becomes embodied within participants' identities. ${ }^{8}$ A third study looks at faculty members' lived experience within social networking sites and demonstrates the tension that exists for participants in managing boundaries for professional and personal connections, using time efficiently, and controlling how one's identity is perceived and constructed online. ${ }^{9}$ While tackling significantly different disciplines, populations, and practical implications, these studies highlight how researching lived experience can be a way of understanding identity, emotions, perceptions, and contexts to develop a more nuanced, complex, and thoughtful understanding of human experience.

Research on the experiences of faculty of color can also offer some insights when considering the experiences of academic librarians of color. One qualitative study on female faculty of color reveals themes that include feelings of isolation at one's institution; perceptions of being underemployed or overused by department or institution; and feelings of being torn between family, community, and career. ${ }^{10}$ Similarly, in an autoethnographic study, Warren-Gordon and Mayes explore their lived experience as African American women faculty members at predominantly white higher education institutions. ${ }^{11}$ The themes that emerge from their experiences include a struggle for acknowledgement of their voice and legitimacy within departments, exclusion from social activities, a struggle to find their "place" within the institution and with colleagues, and overcoming feelings of isolation and frustration. ${ }^{12}$ Another study suggests a practical reason for exploring the experiences of people of color working in academia. Jayakuma, Howard, Allen, and Han find that the quality of experiences at one's institution has the greatest impact on retention of faculty of color, suggesting that experiences influence retention. ${ }^{13}$

There is existing research in library scholarship that explores various types of experiences academic librarians of color have faced. Qualitative interviews with librarians of color who are middle managers express a range of accounts of both positive and negative experiences and reveal a perceived influence of race on one's ability to advance in the profession. ${ }^{14}$ A survey on perceptions of tenure and promotion among academic librarians of color highlights that, while issues related to tenure and promotion such as time management, mentoring, and support are not unique to librarians of color, race is a factor that can complicate these issues and other experiences librarians of color face en route to tenure and promotion. ${ }^{15}$ In Alabi's research on microaggressions in the workplace at academic libraries, the survey finds that 
minority respondents both experience and observe racial microaggressions more often than nonminority respondents to the extent that most minority participants report experiencing a racial microaggression, while very few to no nonminority respondents report observing such encounters. ${ }^{16}$ This research highlights that the experience of encountering or observing microaggressions in the workplace does differ for minority and nonminority respondents. Furthermore, in follow-up research analyzing qualitative responses from the same survey, Alabi explores a range of experiences shared such as encounters of explicit racism, encounters of subtle or implicit racism, and feelings of exclusion or isolation. ${ }^{17}$

Library and information science research has also addressed experiences of specific populations of academic librarians of color. A survey on African American female librarians finds that, while age and length in the profession positively impacts job satisfaction, participants also reported experiences of racial discrimination in the workplace and feelings of isolation. ${ }^{18}$ A survey on librarians in Canada analyzed the responses of those who self-identified as "visible minorities" and reveals themes of loneliness and isolation in the workplace, as well as a perception that colleagues only somewhat or do not welcome and value diversity. ${ }^{19}$ A qualitative study using phenomenological methods explores the experience of native Koreans who are academic librarians in South Korea revealing perspectives on selecting the profession of academic librarianship and concerns with the professionalization and perceived value of librarians in Korea. ${ }^{20}$ Finally, in Hankins and Juarez's book, a broad spectrum of issues relevant to the experiences of librarians of color are addressed, such as initiatives aimed at recruiting and retaining librarians of color, experiences within residency programs, and personal stories and essays from academic librarians of color. ${ }^{21}$

While the existing literature does examine some aspects that comprise experiences of academic librarians of color, a methodological approach that seeks to examine lived experience specifically is missing. This research serves as a foundation for understanding the spectrum of lived experiences of academic librarians of color, considering nuances such as identity, and the contexts from which academic librarians of color originate and the environments through which they navigate.

\section{Methodology}

To explore, uncover, and articulate the lived experience of academic librarians of color, we selected qualitative methods best suited for this research. Our research uses a phenomenological approach, a systematic means of uncovering phenomena of lived experience, ${ }^{22}$ with the purpose of uncovering the range of lived experiences of academic librarians of color and categorizing these experiences into themes. Themes are a way of creating structure out of unstructured data and often simplify the phenomena of lived experience; however, themes do not allow generalizability of these data to an entire population or demographic. ${ }^{23}$

An open-ended questionnaire of eight questions (see appendix A) was administered online through Qualtrics. The questionnaire was intentionally designed to enable free-response in seven of the eight questions, allowing participants the opportunity to share their stories and experiences in their own words, eliminating constraints that would have been imposed by fixed-response questions. ${ }^{24}$

A nonprobabilistic, purposive sampling framework with a homogenous approach was used to identify valid research participants, meaning sampling was not random, and research participants were sought to fit the defined sample population. Valid participants were those who self-identified as persons of color employed as librarians at academic libraries. Recruitment consisted of calls for participation via email through professional library listservs aimed at audiences with racially and/or ethnically diverse 
populations. A total of 180 participants engaged with the questionnaire. Completing all or any questions was not mandatory, thus the range of responses per question falls between 125 and 180, with 148 participants per question as the average and 135 participants per question as the median.

This research has been designed to uncover a comprehensive list of themes, through seeking data saturation, the point at which no new data or codes are produced. Our sampling technique was designed to obtain a broad range of responses sufficient for data saturation and was not designed to seek a statistically significant or representative sample. For qualitative research that uses in-depth interviews, it has been found that a total of twelve interviews are sufficient to produce and reveal 92 percent of the total codes for a given population..$^{25}$ Though our research does not use in-depth interviews, what this finding verifies is that, for qualitative research intended to seek data saturation, a statistically significant sample for a given population is not necessary, and a small sample size is sufficient to reach high levels of data saturation.

The responses collected from the questionnaire form the basis of the raw data analyzed and categorized into themes. An inductive approach to coding was used, meaning codes were generated by reading and synthesizing the collected data. The three coauthors and two graduate students from psychology comprised the coding team and participated in the development of codes, a codebook, and the process of coding responses. Two coders were assigned to each question.

Coders individually generated codes and definitions of codes derived from the responses and then compared their codes with one other coder who analyzed the same responses. Codes were discussed until a set of codes and definitions were agreed upon. A master codebook was created to capture the agreed-upon codes and included definitions of each code and illustrative quotes. Two independent coders analyzed questions $2,3,4,5,6$, and 8 to ensure intercoder-reliability. Codes were reconciled between coders until 100 percent intercoder-reliability was achieved. Question 1 asked respondents to self-identify gender and has been excluded from analysis because we determined to only examine racial/ethnic identities in the scope of this research. While question 7 asked about perceived obligations to the profession, the question did not allow for free-response answers and has been excluded from analysis in recognition that this does not fit with methodology for uncovering lived experience.

\section{Benefits \& Limitations}

The use of an online questionnaire has benefits over other qualitative methodologies, in particular in-depth interviews. An online questionnaire does not require face-to-face interaction, eliminates travel costs for both parties, may be completed at any time and from any location with internet access, allows for consistency in the set of questions asked, and accommodates administering to a large number of participants. In addition, an online questionnaire eliminates bias that may be introduced through face-to-face qualitative methods, such as in-person interviews, where verbal or nonverbal communication from either party may introduce bias when administering or responding to questions. ${ }^{26}$

The limitations of using an online questionnaire instead of other qualitative methods such as in-depth interviews include the lack of ability to probe for depth within responses, to clarify responses, and the use of written communication rather than oral communication. In particular, this research seeks to share the voices of librarians of color; however, "voice," through online questionnaires, can only be communicated in writing. While we recognize that other qualitative methods can provide greater depth and a stronger voice from participants, we decided to use an open-ended, online questionnaire because it enables a large number of people to participate at limited to no 
cost to either researchers or participants, is convenient to complete, and minimizes bias that may occur when administering or responding to face-to-face research instruments.

When conducting research online and when participants self-identify, and self-select into a participant pool, there is an inherent selection bias to this type of sampling. As Elteto, Jackson, and Lim write,

The only thing such a survey can do is to provide descriptive and qualitative results for the group of people who respond. Many libraries... perform surveys of convenience sampling, but it is always an error to assume that the conclusions can necessarily be applied to all library users since self-selected respondents tend to be those with the strongest feelings about the survey topic. ${ }^{27}$

Thus, qualitative results, and the outcomes of this research, cannot and should not be applied broadly or thought of as generalizations about academic librarians of color. In addition, because our sample population was not designed to be statistically significant, our research was also not designed to measure the prevalence, importance, or salience of those themes among academic librarians of color. Data on frequency of themes or percentages of respondents for each theme is excluded from our analysis because the sampling technique and methodology was not designed to illustrate these types of findings.

While we recognize that persons who identify with specific categories of race or ethnicity, such as African Americans, Latina/os, or Asian Americans, may have varying lived experiences as previous research on faculty of color finds, ${ }^{28}$ our research methods intentionally do not apply categories of race or ethnicity on participants. Furthermore, participants were asked to define their race or ethnicity in their own words. Because of the significant variation in self-defined categories of race and ethnicity from participants, we are unable to disaggregate the data into cohesive racial or ethnic categories; thus, we are unable to extract findings that demonstrate variation between and among racial or ethnic categorizations.

In addition, our research explores academic librarianship only in relation to racial and ethnic identity and does not explore lived experience through the lens of other identities such as gender, class, age, nationality, religion, or sexual orientation. We recognize that, as Kimberle Crenshaw has demonstrated through her work on intersectionality, ${ }^{29}$ one's lived experience is shaped by one's multiple identities, sometimes in ways that are not seen through the lens of a single identity. Because the profession is predominantly white, and the data on racial and ethnic demographics shows little change, ${ }^{30}$ we believe it is important to look specifically at racial and ethnic identity and the lived experience of people of color in the profession, which provides a foundation for future research that may explore specific categories of race or ethnicity, or intersectional identities.

\section{Research Findings}

The data reveal twenty-two themes related to the contexts, identities, and lived experiences of academic librarians of color. Appendix B provides a comprehensive list of all the themes uncovered. Direct quotes from the data collected are used throughout the findings to illustrate the themes. Direct quotes are reproduced as written or, on occasion, edited for length into excerpts, honoring the voices of participants.

\section{Context}

Respondents shared perspectives on two distinctive contexts that may contribute to shaping their own experiences as academic librarians of color: the context of racial and ethnic composition at one's institution and the context of family expectations on career 


\section{Lived Experience of Academic Librarians of Color 881}

choice. Respondents were asked to describe the racial and ethnic composition of the libraries and institutions where they work. Respondents see this composition in one of three ways. The first is a perception that the composition of library employees is less diverse than the racial and ethnic composition of the student population:

The college library where I work has a very diverse student population (45\% being non-white), being a community college in an urban setting. The staff in the college and library definitely does not reflect this degree of diversity - although understanding and accepting diversity is part of its mission.

The second is a perception that the racial and ethnic composition of library employees is about the same as the student population: "both groups are quite mixed." The third is a perception that the demographics of library paraprofessionals and staff are more diverse than the demographics of librarians: "the ratio of diversity is less than the campus and the library's diversity comes more from staff than librarians." Notably, no responses indicate a perceived composition of library employees that is more racially and ethnically diverse than the student population.

Respondents also grapple with and share their perspectives on their parents and family expectations on career choice. Six themes emerged: financial stability, social status, education, happiness, marriage and family, and the theme we coded as "discouraging ambition."

The theme of financial stability includes comments regarding upward economic mobility, pay, and monetary rewards. Some respondents write about how the pay of librarians does not align with their family expectation of attaining a high-paying job:

Family expectation was to work hard and get a well paying job. Librarianship does not fit into my family's expectation at all. I'm a first generation college student and the second person in my extended family to receive a graduate degree. They don't really understand what I do. Other family members of my generation chose more high paying and prestigious careers.

In addition, some responses also describe family expectations to seek specific types of positions that are perceived as more financially lucrative:

My parents expected me to work in a for-profit, probably corporate environment because it traditionally means higher pay. They were a little confused by my career choice, but because they are from an older generation, they saw the benefit as me being able to keep a job for as long as I wanted.

Similar to the theme of financial stability, the theme of social status describes perceptions respondents have about their families' expectations and values with regard to title, prestige, and brand of profession. For some, respondents perceive that their families do not see librarianship as a prestigious profession: "doesn't really match their expectations; status of the library profession remains low in a lot of communities, also not really perceived as being a professional career." Other respondents describe how academic librarianship, their specific position, or their institution is viewed as prestigious by family:

Librarianship isn't so bad since I'm at an academic institution that's world renowned but it's not what anyone expected or really wanted. I think everyone would be less happy if I ended up at a community college or public library or 4 year institution no one had ever heard of or thought very little of. 
The theme of education describes either a tangible or explicit goal to "finish school" or as something less concrete: "lifelong learning." Both ways of describing education reflect the value respondents' families place on some form of education: "it was hoped that I would attend college, but never imagined that I would attend graduate school." Furthermore, some participants also mention that their parents had not attended college: " $m y$ parents just wanted me to go to college. Neither of them attended college. I don't think they ever thought of librarianship for me." For some, as a first-generation college student, their families had expectations on pursuing more prestigious or higher-paying careers: "as one of the first members of my family to go to college they expected the usual doctor or lawyer. Many of my family members still don't understand what I do for a living." Throughout the themes of financial stability, education, and social status, some respondents express that their families lack an understanding of what librarianship is:

They had much higher expectations of me in terms of financial success and career prestige. However, the fact that I am the first to have earned an advanced degree has meant a lot to them. Most of my family doesn't know what a librarian does, though, despite my efforts to educate them (although they don't really seem to care).

Happiness emerges as a theme, describing the perception that attaining happiness is an important family value, often over attainment of other goals such as financial stability, education, or prestige: "my parents did not have any expectations. They wanted me to be happy and successful at whatever [profession] I chose." At times, attainment of happiness through pursuit of librarianship came at the expense of financial stability:

I remember my Mother telling me that I should go into a career that would fulfill me, since I would have to work for a living find something that you love! Money does not make you happy, she said. Be happy $\mathcal{E}$ healthy and have a wonderful life. I completed my educational goals, I love being a librarian (most of the time), I am happy $\mathcal{E}$ healthy (even without benefits) and I am broke. It is a noble profession!

Finally, two additional themes are expectations of marriage and family, and "discouraging ambition." The theme of marriage and family describes the perception that getting married and raising a family is more important to some respondents' families than pursuing career ambitions: "expectations was to get married after high school and raise a family. No working encouragement from either parent. Definitely not college." The theme of "discouraging ambition" describes a perceived lack of expectations about career or otherwise from family: "my immigrant parents expectations for me as a woman were very low," or a perception that family does not support one's career aspirations. Unlike the other themes that prominently feature professional ambition, both of these themes speak to a perceived lack of expectations from parents and family regarding pursuit of a career.

\section{Identity}

Our findings on identity are categorized into two distinctive concepts: self-identification, the words participants use to define themselves racially and/or ethnically; and identity theory, the ways in which the constructs of racial, ethnic, and professional identity are found in participants' responses. From these concepts the themes of "own words," "sense of otherness," "more than a job," and "sense of connectedness" emerge.

The theme of "own words" describes how respondents define themselves racially and/ or ethnically when given the opportunity to use their own words, ultimately resulting in 63 different ways respondents defined their racial and/or ethnic identity. Responses range from language that describes broad racial and ethnic categories ("African American," 
"Asian American," "Biracial") to more specific descriptions ("White, Mexican-American," "Middle Eastern and Asian," "Puerto Rican from New York City," "Black but not African American they are different"). Respondents self-identity with the words or terminology they choose to employ ("Chicana," "Latina," "Latino," "Indigenous," "African Canadian," "Black American"), using terminology that falls outside categorizations defined by institutions that shape our personal and professional lives. ${ }^{31}$ When given the opportunity to use one's own words to self-identify racially and ethnically, the results cannot easily be categorized.

Respondents were asked to consider how librarianship influenced their sense of self and sense of identity. The themes of a "sense of otherness," "more than a job," and "a sense of connectedness" emerged from the responses. The theme of a "sense of otherness" describes feelings of marginalization: "I perhaps feel more marginalized being among mostly white colleagues." The theme also invokes concepts of racial identity theory, including the process of overcoming internalized racism to achieve a self-affirming racial identity: ${ }^{32}$ "I think it makes me gravitate towards showcasing more archives or books that are written or by people of color because I see the lack of diversity in the collections we acquire." The theme also addresses racial identity theory through how an individual constructs one's identity in response to an oppressive and racialized society: ${ }^{33}$

I definitely feel like being Middle Eastern in the current political climate makes me more aware of being a "representative" in all of my behavior.

It has informed me of the White-supremacist Colonial System we live within. It has made me question information because almost ALL information I encounter, or will encounter is impacted by White Supremacy.

The theme of a "sense of otherness" highlights that racial identity theory manifests for some respondents through feelings of marginalization, an awareness of and navigation in systems of power and oppression, and development of an identity in response to racialized and oppressive institutions, culture, and society.

The theme of "more than a job" speaks to professional identity theory, the internalization and socialization of a profession's culture, values, and identity, ${ }^{34}$ and is reflected in one of two ways: 1 ) a sense that working as a librarian is more than a job to an individual; or 2) a sense of internalization of the values attributed to the profession.

Being a librarian is more than a job to me; it is part of my identity.

I'm much more concerned about freedom of information and how companies like Facebook, etc. keep tabs on our personal information.

For some respondents, a professional identity of librarianship resonates strongly:

Ifeel that the librarian profession has become a proving ground for me to nurture various aspects of my identity so they are becoming cohesive together and finding expression and impact through meaningful service and work. In this sense, librarianship functions as a vocation, a calling, not merely a career, profession, or occupation.

While for others, professional identity is less important:

It's an important part of my identity overall, but not the primary driver. My personal roles are much more important. But it does make me feel like I can contribute in other roles in ways that some others can't, particularly in accessing and sharing information. 
In addition, some responses portray concepts found in both professional and racial identity theory. For some respondents, the concepts of racial and professional identity theory complement each other, where values of the profession are used to develop selfaffirming racial identities: "it has made me more aware of issues such as the "digital divide", and how important it is for young people of color to see themselves and their history in the library, especially in the special collections, where I've made my career." In other responses, a tension exists between the two identity theories:

I feel librarianship has made my sense of identity stronger. As a graduate student I learned that libraries contributed a lot to the fight for intellectual freedom... At the same time, I learned that these great public institutions, which now do so much for the freedom and equality for their users, were not above limiting information access for minorities during and before the civil rights era. Now, as a librarian of color, I feel I have a little bit more of an obligation to provide a consistent and equal level of service in each interaction with a member of the community.

The theme of "more than a job" illustrates that the concepts of professional identity theory may resonate to varying degrees, complement, or create tension with how respondents see themselves.

The theme of "sense of connectedness" reflects ethnic identity theory, the degree to which an individual identifies with the values, norms, languages, and beliefs, has a sense of membership and belonging to one's own ethnic background. ${ }^{35}$ Some participants have a strong sense of connectedness, while others lack or reject a sense of connectedness, highlighting that both express ethnic identity theory.

I think that my positive experiences with the Spectrum community has helped to foster my positive ethnic identity.

\section{I feel more disconnected from my cultural heritage because of the homogenous community and lack of diversity in my institution and profession. I have debated leaving the profes- sion because of how isolated from other minority members.}

Both of the examples illustrate ways in which a sense of connectedness to one's own ethnic background can be fostered or inhibited by the profession. However, the second example illustrates what may be at stake when one feels not only a lack of connectedness with one's ethnic background, but also marginalization and isolation as a person of color in the profession.

\section{Lived Experience in the Profession}

Participants were asked to share stories of experiences as people of color in the workplace, at libraries, within institutions, or in the profession. Nine themes emerge: questioning of authority; competency; microaggressions; unfair treatment; discrimination; distinctive contribution; level of service; visibility leads to approachability; and multiracial/biracial and light-skinned or white appearance.

The theme of "questioning of authority" describes the lived experience of being second-guessed in one's position of authority, while the theme of "competency" describes the lived experience of being second-guessed in one's professional skills and knowledge. Many respondents share stories similar to these two anecdotes:

I am in a management position. I do not believe I would have the amount of second guessing of my decisions if I were white. 
A few times I have felt that people have not respected my intelligence until it has been demonstrated to them.

Other stories that fall under these two themes involve respondents interacting with patrons who question a librarian's competency or position of authority: "pretty much daily, when patrons or guests ask to speak to an administrator or manager (I'm a library director) and they seem surprised when I introduce myself as such." Some respondents share stories with more blatant forms of denial of librarianship such as being ignored, dismissed, or bypassed on the job:

Once I was at the reference desk and a student came up to ask a question. He asked to speak to a "real librarian" and I was like, that's me. Then he was like "no, I mean a real librarian." Not sure if it's because I looked young, or wasn't an old white lady, but he had a hard time believing I was a librarian. My coworker also felt that it was because I was a person of color (she was one too).

Many of the experiences conveyed under the themes of "questioning authority" and "competency" might be seen as encounters of microaggressions or discrimination; however, we coded these responses under distinct themes separate from the themes of microaggressions and discrimination to highlight the specific experiences where authority and competency are questioned.

As respondents' stories demonstrate, the lived experience of an academic librarian of color may include encounters of microaggressions, discrimination, prejudicial treatment in one-on-one interactions with colleagues or at the institutional level through systemic discrimination and oppression. While microaggressions are defined as "everyday verbal, nonverbal, and environmental slights, snubs, or insults, whether intentional or unintentional, which communicate hostile, derogatory, or negative messages to target persons based solely upon their marginalized group membership," ${ }^{36}$ for the purposes of coding, the theme of "microaggressions" primarily reflects verbal slights, snubs, or insults experienced.

I work with a white librarian who is gay and politically active, but is, in my opinion, not sensitive to the subtle ways bias toward people of color express themselves. She once said to me, "I know you have trouble being assertive, I understand it's part of your culture, but you have to be more aggressive sometimes." I told her I resented the implication that, just because I am Asian, I fall into that stereotype of being "passive, timid, non-aggressive." I told her that what she said was very offensive and I reported this incident to the Chief Librarian.

Both the themes of "unfair treatment" and "discrimination" describe the lived experience of prejudicial treatment of an individual based on their actual or perceived membership in a marginalized group. In our coding, the theme of "unfair treatment" describes the lived experience of prejudicial treatment felt by respondents occurring at institutional or systemic levels: "promotions to leadership positions are given to Caucasian librarians. I had not thought much about these trend[s] until a faculty of color pulled me aside to express concerns because he felt that I was being passed over by less qualified people due to my race." For the purposes of coding, the theme of "discrimination" describes the lived experience of prejudicial treatment or discrimination that occur in an interpersonal or one-on-one context: "I've been bullied and talked down to by my colleagues and director."

The theme of "distinctive contribution" describes the lived experience where respondents felt that because of their racial/ethnic identity they have been able to contribute in ways that others could not, better serving students, patrons, or their institutions. 
Being able to speak Spanish, while not dependent on my own ethnicity, has been something I can use every once in a while when on the reference desk or in creating Spanishlanguage library materials. I am much more aware of how our staff interacts with students of color and am more interested in making sure our library is welcoming to all students regardless of color.

Similar to distinctive contributions, the theme of service describes the roles some respondents play to serve and meet the needs of patrons or specific communities, often of a similar racial or ethnic background as the respondent. Many of these responses highlight a positive value for the respondent, and some responses share a sense of mutual positive value for respondent and the served community.

\section{I have served on several awards committees for students of color in SAA (Society of American Archivists). Selecting a student to win an award is always a great experience. I won several of these awards and I know how valuable and important they have been in keeping me in this career, and thus increasing the profession's diversity.}

The term "visibility leads to approachability" is derived from previous research on librarian approachability. ${ }^{37}$ The researchers of that study found that AfricanAmerican participants, who were students, faculty, and members of the university community, perceived African-American librarians as more approachable than white librarians, suggesting that librarians of color are perceived as more approachable to students of color of the same racial or ethnic background. The theme of "visibility leads to approachability" emerges from stories where respondents feel that they are more approachable to patrons of similar racial or ethnic backgrounds at their libraries.

Arab students came to me after 9/11 for information. They told me they were scared of people from the dominant culture.

Many students of color seek me out to teach them library skills. I am approachable and relatable. I think if they see I have made it through library school, they can too.

Finally, the theme of "multiracial/biracial, light-skinned, or white-skinned appearance" emerges from respondents who mention being multiracial/biracial, light-skinned, or white-skinned and having their racial/ethnic identities questioned or made invisible in the workplace. These respondents describe how their identity has been questioned because of how they look, how their identity has felt invisible to others, and how being light-skinned has afforded some privilege: "because I look white I have not been the subject of direct racism or microaggression. If anything I have been privy to negative conversations about people of color by my colleagues/students without them realizing they may be offending me." Some of the responses describe a sense of dissonance between the identity the participant holds to be true and a rejection or invisibility of that identity by others: "really my issue is that people often want to define my ethnicity for me. Because I don't look like what they expect a Latina to look like that I am somehow not authentic." Furthermore, some of the responses evoke a sense of forced "passing," meaning an imposed White identity from others, and denial of one's identity as a person of color: "I have white skin privilege and often people assume I am white or even if they know I am not they 'forget' that I am not-so they make my identity invisible - and assume that I fit where they want me to in their ethnocentric views." 


\section{Discussion}

Lived experience can be used to understand academic librarianship and work as it manifests and is experienced differently and uniquely, particularly for librarians of color. It incorporates who people are, the social context through which an experience takes place, and validates perceptions, feelings, and senses of self as components of human experience. While our findings are viewed through participants' perceptions, the themes highlight the multitude of factors that encompass the human experience of being a librarian of color in an academic library. Our findings allow the profession to begin exploring what it means to be a person of color working in a predominantly white profession and predominantly white institutions, and how academic librarians of color who participated in this research internalized their interactions within this context.

Academic libraries and the institutions where librarians work are environments where one's identity is shaped by the social context. ${ }^{38}$ Institutions can also be contexts "in which identities are tools for shaping, reinforcing or challenging contexts, norms, and practices." ${ }^{39}$ In other words, academic libraries, as social contexts, both shape and are shaped by the identities of academic librarians. Thus, the predominantly white profession of academic librarianship shapes the identities of academic librarians of color, but it is also shaped by, challenged, and reinforced by the identities of academic librarians of color. Our findings on the perceived minimal racial and ethnic diversity of the workplace and institution raises questions for further study on how this perception may shape the identity and lived experience of not only academic librarians of color, but of all employees at academic libraries and the patrons they serve. How might an academic library, as a social context, shape and be shaped by the perceived racial and ethnic demographics of its librarians, employees, students, and patrons?

Research outside library and information science also suggests that the role of family in one's career choice and professional development can be influential in shaping one's experience as a professional, particularly through the ways family can provide support including emotional support, networking, esteem, information, and tangible resources. ${ }^{40}$ Our findings begin to highlight the types of expectations families may have for the participants, but further research could explore how those expectations influence and shape an academic librarian of color's path in the profession. Further research could also explore how family expectations shape one's professional identity or sense of self as a librarian, as well as one's relational identity, for example as a child, grandchild, cousin, mother, or father.

Our findings also begin to illustrate the ways in which participants influence and shape academic libraries and institutions through the themes of "distinctive contributions," "level of service," and "visibility leads to approachability." These three themes highlight ways in which librarians of color have shaped the services, patron interactions, or greater community because of one's racial/ethnic and personal identity. Furthermore, these are consistent with previous qualitative research on identity and librarians of color, which found similar themes regarding positive contributions made to institutions and feelings of satisfaction, and the perception of successfully building of trust with students of color, as well as faculty and donors of color. ${ }^{41}$

The theme of "more than a job" reveals that the values and identity of librarianship are internalized by some respondents. Existing literature argues that stereotypes surrounding librarianship need to be challenged and deconstructed to control the image as well as identity of the profession. ${ }^{42}$ Another study argues that librarianship is a process of constant change and periodic reorienting of self to the profession that is sustained as an aspect of professional identity throughout one's career: 
Academic librarians do not "become" academic librarians like one switches on a light, and they do not stop being academic librarians when they dramatically shift their work roles. Instead, the participants are always becoming librarians because they operate in a perpetually shifting professional terrain. ${ }^{43}$

An additional study addresses not only professional identity, but also the relationship between social identity and role performance among academic librarians. ${ }^{44}$ It covers age/generational identity, gender identity, and race/ethnicity identity and finds that social identities do matter in the ways librarians perform their work. ${ }^{45}$ Further research could explore which norms, values, and ideas are being internalized, what professional identity looks like as the profession changes, and how this may shape roles and work performed by academic librarians of color.

The themes of "questioning of authority" and "questioning competency" highlights a tension that may exist between identity and experience. In identity theory, identity verification is the idea that one perceives that others see them in the same way they see themselves. ${ }^{46}$ Feelings of negative emotions result when feedback loops indicate that the identity one holds to be true is not recognized by others. ${ }^{47}$ The theme of "multiracial/biracial, light-skinned, or white-skinned appearance" also highlights a tension between the racial/ethnic identity one may hold and the questioning, denial, or invisibility of that identity by others in the workplace. All of these themes reflect a lived experience with an incongruous feedback loop with respect to identity verification.

What the themes of "questioning of authority" and "questioning competency" reveal is that, for some individuals, the lived experience of being an academic librarian comes with a challenge to that professional title. Not everyone is granted the position and status of academic librarian through title alone; some academic librarians of color must perform, demonstrate, and convince patrons and colleagues of their place in the profession. Further research could examine the tension between librarians of color internalizing librarianship as a professional identity and the experience of having that identity questioned or perceived differently by others.

In considering race and specific dimensions of race-skin color, categorical race, and experiences of discrimination - race itself can also be a lived experience. ${ }^{48}$ The repeated similarity of experiences categorized into themes "questioning of authority," "questioning competency," "microaggressions," "unfair treatment," and "discrimination," as well as expressions of a sense of otherness, marginalization, and oppression-hallmarks of racial identity theory-supports the notion that being a person of color in an academic library is a lived experience and differs from the lived experience of a white colleague. Further research could examine specific nuances of these themes, such as environmental microaggressions, which are "racial assaults, insults, and invalidations... manifested on systemic and environmental levels," ${ }^{49}$ and how the overwhelming whiteness of an institution shapes the lived experience of an academic librarian of color who works there. The presence of the themes "questioning of authority," "questioning competency," "microaggressions," "unfair treatment," and "discrimination" found at interpersonal and systemic levels in the lived experience for some participants reveals the multiple levels of barriers and challenges that can comprise the lived experience of being a person of color working in an academic library.

\section{Conclusion}

This research highlights how the contexts of professional and personal lives, selfidentification, sense of self as examined through racial, ethnic, and professional identity 
theory can shape the lived experience of academic librarians of color. Additionally, lived experience can be complex, nuanced, and varied. This research leaves ample room for further exploration. It is recommended that future research explore the themes introduced in this article through a methodological approach that continues to seek an understanding of lived experience and honors the voices of participants. Furthermore, some of our respondents describe experiences attributed to intersectional identities or raise questions about experiences that invoke the possibility of intersectionality. To repeat or examine any of these themes in future research, addressing intersectional identities when considering research questions and methodology would be prudent. Finally, further research could examine how the themes uncovered in this research can be used to think critically about the identity of academic librarians collectively, predominantly white, cisgender, heterosexual, female, and able-bodied, and what this means to the lived experience of marginalized and all people working in academic libraries. 


\section{APPENDIX A. Librarians of Color: Perceptions of Professional and Racial Identity in Academic Libraries Questionnaire}

1. Please identify your gender:

2. How do you identify racially and/or ethnically?

3. Describe the racial/ethnic diversity of your institution's student population. How does it compare to that of the library and institution overall?

4. What were your parents'/guardians'/family's expectations for you in regard to work and profession? How does librarianship fit in with their expectations?

5. Can you describe an experience that has been positive because you are a librarian of color?

6. Can you describe an experience you have had as a librarian of color that you believe you may not have had if you were white?

7. How much of an obligation do you feel to contribute to the library profession or your academic institution (including users, faculty, colleagues, and so on) as a librarian of color?

$\square \quad$ None at all

$\square \quad$ Slight amount

$\square \quad$ Moderate amount

$\square \quad$ A lot

$\square \quad$ A great deal

8. How has librarianship impacted your overall sense of identity (that is, ethnic, cultural, political, professional, racial, religious, sexual, and any other identity)? 


\begin{tabular}{|c|c|c|}
\hline \multicolumn{3}{|c|}{$\begin{array}{l}\text { APPENDIX B } \\
\text { Thematic Findings on Context, Identity, and Lived } \\
\text { Experiences of Academic Librarians of Color }\end{array}$} \\
\hline Heading & Themes & Illustrative Excerpt \\
\hline \multirow[t]{3}{*}{$\begin{array}{l}\text { Context: } \\
\text { Institutional } \\
\text { Composition }\end{array}$} & $\begin{array}{l}\text { Library employees } \\
\text { less diverse than } \\
\text { student population }\end{array}$ & $\begin{array}{l}\text { "Diverse student body. The library is surprisingly } \\
\text { non-diverse." }\end{array}$ \\
\hline & $\begin{array}{l}\text { Diversity of library } \\
\text { employees and } \\
\text { student population } \\
\text { about the same }\end{array}$ & $\begin{array}{l}\text { "Both the student body and the library and very } \\
\text { diverse. The institution as a whole is somewhat } \\
\text { diverse." }\end{array}$ \\
\hline & $\begin{array}{l}\text { Library } \\
\text { paraprofessionals and } \\
\text { staff more diverse } \\
\text { than librarians }\end{array}$ & $\begin{array}{l}\text { "We have some diversity, but most ethnic/racial } \\
\text { minorities occupy staff positions, not librarian } \\
\text { ones." }\end{array}$ \\
\hline \multirow{6}{*}{$\begin{array}{l}\text { Context: } \\
\text { Family } \\
\text { Expectations }\end{array}$} & Financial stability & $\begin{array}{l}\text { "Family expectation was to work hard and get a } \\
\text { well-paying job." }\end{array}$ \\
\hline & Education & $\begin{array}{l}\text { "My parents just wanted me to go to college. } \\
\text { Neither of them attended college." }\end{array}$ \\
\hline & Social status & $\begin{array}{l}\text { "Go to college and major in something practical } \\
\text { like business, econ, pre-med stuff or prep for law } \\
\text { school." }\end{array}$ \\
\hline & Happiness & $\begin{array}{l}\text { "My parents did not have any expectations. } \\
\text { They wanted me to be happy and successful at } \\
\text { whatever profession I chose." }\end{array}$ \\
\hline & Marriage \& family & $\begin{array}{l}\text { "Expectation was to get married after high } \\
\text { school and raise a family. No working } \\
\text { encouragement from either parent. Definitely not } \\
\text { college." }\end{array}$ \\
\hline & $\begin{array}{l}\text { Discouraging } \\
\text { ambition }\end{array}$ & $\begin{array}{l}\text { "My immigrant parents' expectations for me as a } \\
\text { woman were very low. They expected that I would } \\
\text { get married young and raise a family." }\end{array}$ \\
\hline \multirow[t]{4}{*}{ Identity } & Own words & $\begin{array}{l}\text { "Filipino"; "American (black)"; "Hapa: half } \\
\text { Japanese American and half Caucasian (German } \\
\text { and Danish)" }\end{array}$ \\
\hline & Sense of otherness & $\begin{array}{l}\text { "I definitely feel like being middle eastern in the } \\
\text { current political climate makes me more aware of } \\
\text { being a 'representative' in all of my behavior." }\end{array}$ \\
\hline & More than a job & $\begin{array}{l}\text { "Being a librarian is more than a job to me; it is } \\
\text { part of my identity." }\end{array}$ \\
\hline & $\begin{array}{l}\text { Sense of } \\
\text { connectedness }\end{array}$ & $\begin{array}{l}\text { "I think that my positive experiences with the } \\
\text { Spectrum community has helped to foster my } \\
\text { positive ethnic identity." }\end{array}$ \\
\hline
\end{tabular}




\begin{tabular}{|c|c|c|}
\hline $\begin{array}{l}\text { Lived } \\
\text { Experience }\end{array}$ & $\begin{array}{l}\text { Questioning of } \\
\text { authority }\end{array}$ & $\begin{array}{l}\text { "I am in a management position. I do not believe } \\
\text { I would have the amount of second guessing of } \\
\text { my decisions if I were white." }\end{array}$ \\
\hline & $\begin{array}{l}\text { Questioning of } \\
\text { competency }\end{array}$ & $\begin{array}{l}\text { "People questioning my credentials and } \\
\text { experiences." }\end{array}$ \\
\hline & Microaggressions & $\begin{array}{l}\text { "I sometimes have students or faculty ask me } \\
\text { where I'm from after seeing my last name on the } \\
\text { reference desk name plate, the implication being } \\
\text { that I am not from the United States." }\end{array}$ \\
\hline & Unfair treatment & $\begin{array}{l}\text { "I was at an institution where I felt I was not } \\
\text { given little, if any, support to do my job superbly. } \\
\text { Some would say that I was thrown in the deep end } \\
\text { to see how well I could float." }\end{array}$ \\
\hline & Discrimination & $\begin{array}{l}\text { "I was working at the reference desk with a white } \\
\text { librarian, and a white older student came up to } \\
\text { the desk. The white librarian was busy, so I asked } \\
\text { if I could help. He ignored me (I said it twice, } \\
\text { and I know he heard me because he looked at me } \\
\text { when I spoke). He waited until she was finished } \\
\text { so she could help him." }\end{array}$ \\
\hline & $\begin{array}{l}\text { Distinctive } \\
\text { contributions }\end{array}$ & $\begin{array}{l}\text { "Being able to speak Spanish, while not } \\
\text { dependent on my own ethnicity, has been } \\
\text { something I can use every once in a while when } \\
\text { on the reference desk or in creating Spanish- } \\
\text { language library materials." }\end{array}$ \\
\hline & Level of service & $\begin{array}{l}\text { "This is probably a matter of both my ethnicity } \\
\text { and my relatively young age, but I have had } \\
\text { very positive experiences in outreach to various } \\
\text { student groups around campus. I've been well } \\
\text { received by the Black Student Alliance, for } \\
\text { example, in visits to their meetings." }\end{array}$ \\
\hline & $\begin{array}{l}\text { Visibility leads to } \\
\text { approachability }\end{array}$ & $\begin{array}{l}\text { "Arab students came to me after } 9 / 11 \text { for } \\
\text { information. They told me they were scared of } \\
\text { people from the dominant culture." }\end{array}$ \\
\hline & $\begin{array}{l}\text { Multiracial/biracial, } \\
\text { light-skinned or } \\
\text { white-skinned } \\
\text { appearance }\end{array}$ & $\begin{array}{l}\text { "I have white skin privilege and often people } \\
\text { assume I am white or even if they know I am } \\
\text { not they 'forget' that I am not-so they make my } \\
\text { identity invisible." }\end{array}$ \\
\hline
\end{tabular}

\section{Notes}

1. Max Van Manen, Phenomenology of Practice: Meaning-Giving Methods in Phenomenological Research and Writing (Walnut Creek, Calif.: Left Coast Press, Inc., 2014), 39.

2. Virginia Eatough and Jonathan A. Smith, "Interpretative Phenomenological Analysis," in The SAGE Handbook of Qualitative Research in Psychology, eds. Carla Willig and Wendy StaintonRogers (London, U. K.: SAGE Publications Ltd., 2008), 181, doi:10.4135/9781848607927.

3. Van Manen, Phenomenology of Practice, 39.

4. Max Van Manen, Researching Lived Experience: Human Science for an Action Sensitive Pedagogy, SUNY Series in the Philosophy of Education (Albany, N.Y.: State University of New York Press, 1990), 184. 


\section{Lived Experience of Academic Librarians of Color 893}

5. Robin Boylorn, "Lived Experience," in The SAGE Encyclopedia of Qualitative Research Methods, ed. Lisa Given (Thousand Oaks, Calif.: SAGE Publications, Inc., 2008), 490, doi:10.4135/9781412963909.n250.

6. Boylorn, "Lived Experience," 490.

7. Carolyn Cole and Helen Wilson Harris, "The Lived Experiences of People Who Identify as LGBT Christians: Considerations for Social Work Helping," Social Work \& Christianity 44 (2017).

8. Benjamin Milbourn, Beverley McNamara, and Angus Buchanan, "The Lived Experience of Everyday Activity for Individuals with Severe Mental Illness," Health Sociology Review 24, no. 3 (Sept. 2, 2015): 270-282, doi:10.1080/14461242.2015.1034747.

9. George Veletsianos and Royce Kimmons, "Scholars and Faculty Members' Lived Experiences in Online Social Networks," The Internet and Higher Education 16 (Jan. 2013): 43-50, doi:10.1016/j.iheduc.2012.01.004.

10. Caroline Sotello Viernes Turner, "Women of Color in Academe: Living with Multiple Marginality," Journal of Higher Education 73, no. 1 (2002): 74-93.

11. Kiesha Warren-Gordon and Renae D. Mayes, "Navigating the Academy: An Autoethnographic Approach to Examining the Lived Experience of African American Women at Predominantly White Institutions of Higher Education," Qualitative Report 22, no. 9 (2017): 2356-66.

12. Warren-Gordon and Mayes, "Navigating the Academy."

13. Uma M. Jayakumar et al., "Racial Privilege in the Professoriate: An Exploration of Campus Climate, Retention, and Satisfaction," Journal of Higher Education 80, no. 5 (2009): 538-63.

14. Kimberley Bugg, "The Perceptions of People of Color in Academic Libraries Concerning the Relationship between Retention and Advancement as Middle Managers," Journal of Library Administration 56, no. 4 (May 18, 2016): 428-43, doi:10.1080/01930826.2015.1105076.

15. Ione T. Damasco and Dracine Hodges, "Tenure and Promotion Experiences of Academic Librarians of Color," College E Research Libraries 73, no. 3 (May 1, 2012): 279-301, doi:10.5860/ crl-244.

16. Jaena Alabi, "Racial Microaggressions in Academic Libraries: Results of a Survey of Minority and Non-Minority Librarians," The Journal of Academic Librarianship 41, no. 1 (Jan. 2015): 47-53, doi:10.1016/j.acalib.2014.10.008; Jaena Alabi, “'This Actually Happened': An Analysis of Librarians' Responses to a Survey about Racial Microaggressions," Journal of Library Administration 55, no. 3 (Apr. 3, 2015): 179-91, doi:10.1080/01930826.2015.1034040.

17. Jaena Alabi, "This Actually Happened," 179-91.

18. Joyce K. Thornton, "African American Female Librarians: A Study of Job Satisfaction," Journal of Library Administration 33, no. 1/2 (June 2001): 141-64, doi:10.1300/J111v33n01_10.

19. Joyce K. Thornton, "African American Female Librarians: A Study of Job Satisfaction," $141-64$.

20. Kaetrena Davis Kendrick, "The Experience of Korean Academic Librarianship: A Phenomenological Study," IFLA Journal 40, no. 4 (Dec. 2014): 267-79, doi:10.1177/0340035214543165.

21. Where Are All the Librarians of Color? The Experiences of People of Color in Academia, eds. Rebecca Hankins and Miguel Juárez (Sacramento, Calif.: Library Juice Press, 2015).

22. Van Manen, Researching Lived Experience.

23. Van Manen, Researching Lived Experience, 87-88.

24. Greg Guest, Emily E. Namey, and Marilyn L. Mitchell, Collecting Qualitative Data: A Field Manual for Applied Research (Thousand Oaks, Calif.: SAGE Publications, Inc., 2013), 11.

25. Greg Guest, Arwen Bunce, and Laura Johnson, "How Many Interviews Are Enough? An Experiment with Data Saturation and Variability," Field Methods 18, no. 1 (Feb. 2006): 59-82, doi:10.1177/1525822X05279903.

26. Albert Mills, Gabrielle Durepos, and Elden Wiebe, Encyclopedia of Case Study Research (Thousand Oaks, Calif.: SAGE Publications, Inc., 2010), doi:10.4135/9781412957397.

27. Sharon Elteto, Rose M. Jackson, and Adriene Lim, "Is the Library a 'Welcoming Space'? An Urban Academic Library and Diverse Student Experiences," portal: Libraries and the Academy 8, no. 3 (2008): 331, doi:10.1353/pla.0.0008.

28. Uma M. Jayakumar et al., "Racial Privilege in the Professoriate: An Exploration of Campus Climate, Retention, and Satisfaction," Journal of Higher Education 80, no. 5 (2009): 538-63.

29. Kimberle Crenshaw, "Mapping the Margins: Intersectionality, Identity Politics, and Violence against Women of Color," Stanford Law Review 43, no. 6 (July 1991): 1241, doi:10.2307/1229039.

30. Diversity Counts Office for Research and Statistics, Office for Diversity, American Library Association, "Diversity Counts 2012 Tables," available online at www.ala.org/offices/sites/ala. org.offices/files/content/diversity/diversitycounts/diversitycountstables2012.pdf [accessed 1 May 2017].

31. When comparing the language that participants used for self-identification to terminology used for race and ethnicity in both the 2010 U.S. Census and ALA's Diversity Counts survey, a plurality of responses used language not found in the 2010 U.S. Census, while a majority of 
responses used language not found in the ALA Diversity Counts survey. Diversity Counts Office for Research and Statistics, Office for Diversity, American Library Association, "Diversity Counts 2012 Tables," available online at www.ala.org/offices/sites/ala.org.offices/files/content/diversity/diversitycounts/diversitycountstables2012.pdf [accessed 1 May 2017]; United States Census Bureau, "2010 Census Form," available online at https://www.census.gov/history/pdf/2010questionnaire. pdf [accessed 1 May 2017].

32. Kevin Cokley, "Critical Issues in the Measurement of Ethnic and Racial Identity: A Referendum on the State of the Field," Journal of Counseling Psychology 54, no. 3 (2007): 225, doi:10.1037/0022-0167.54.3.224.

33. Cokley, "Critical Issues in the Measurement of Ethnic and Racial Identity," 225.

34. Edgar H. Schein, Career Dynamics: Matching Individual and Organizational Needs (Reading, Mass.: Addison-Wesley, 1978), 32.

35. Jean S. Phinney, "When We Talk about American Ethnic Groups, What Do We Mean?" American Psychologist 51, no. 9 (1996): 918; Sapna Cheryan and Jeanne L. Tsai, "Ethnic Identity," in The Handbook of Asian American Psychology, eds. Lee C. Lee and Nolan W.S. Zane (Thousand Oaks, Calif.: Sage Publications, Inc., 1998), 125.

36. Derald Wing Sue, "Microaggressions: More Than Just Race," Psychology Today (Nov. 17, 2010), available online at www.psychologytoday.com/blog/microaggressions-in-everydaylife/201011/microaggressions-more-just-race [accessed 18 September 2018].

37. Jennifer L. Bonnet and Benjamin McAlexander, "Structural Diversity in Academic Libraries: A Study of Librarian Approachability," Journal of Academic Librarianship 38, no. 5 (2012): 277-86.

38. Jan E. Stets and Richard T. Serpe, "Identity Theory," in Handbook of Social Psychology, eds. John DeLamater and Amanda Ward (Dordrecht: Springer Netherlands, 2013), 34, doi:10.1007/97894-007-6772-0_2.

39. Meghan Pifer and Vicki Baker, "Identity as a Theoretical Construct in Research about Academic Careers," in International Perspectives on Higher Education Research, ed. Malcom Tight, vol. 9, Theory and Method in Higher Education Research eds. Jeroen Huisman and Malcolm Tight (Bingley: Emerald Group Publishing Limited, 2013), 115-32, doi:10.1108/S1479-3628(2013)0000009010.

40. Susan D. Phillips, Erin K. Christopher-Sisk, and Kristine L. Gravino, "Making Career Decisions in a Relational Context," Counseling Psychologist 29, no. 2 (Mar. 2001): 232, doi:10.1177/0011000001292002.

41. Karen Downing, "The Relationship between Social Identity and Role Performance among Academic Librarians" (PhD dissertation, University of Michigan, 2009) 193-94, available online at https://deepblue.lib.umich.edu/bitstream/handle/2027.42/62396/kdown_1.pdf;jsessionid=A97 834AFBC252098DB0E8938C3661C16?sequence=1 [accessed 18 September 2018].

42. Nicole Pagowsky and Miriam Rigby, "Contextualizing Ourselves," in The Librarian Stereotype: Deconstructing Perceptions \& Presentations of Information Work, eds. Nicole Pagowsky and Miriam Rigby (Chicago, Ill.: Association of College and Research Libraries, 2014), 1-38, available online at https://core.ac.uk/download/pdf/36692828.pdf [accessed 18 September 2018].

43. Laura Sare and Stephen Edward Bales, "Professional Identity: A Grounded Theory Study of Veteran Academic Librarians," Library Review 63, no. 8/9 (Oct. 28, 2014): 574-89, doi:10.1108/ LR-02-2014-0020.

44. Downing, "The Relationship between Social Identity and Role Performance."

45. Downing, "The Relationship between Social Identity and Role Performance," 196.

46. Jan E. Stets and Richard T. Serpe, "Identity Theory," in Handbook of Social Psychology, eds. John DeLamater and Amanda Ward (Dordrecht: Springer Netherlands, 2013), 35, doi:10.1007/97894-007-6772-0_2.

47. Stets and Serpe, "Identity Theory," 35.

48. John A. Garcia et al., "Race as Lived Experience," Du Bois Review: Social Science Research on Race 12, no. 2 (2015): 349-73, doi:10.1017/S1742058X15000120.

49. Derald Wing Sue et al., "Racial Microaggressions in Everyday Life: Implications for Clinical Practice," American Psychologist 62, no. 4 (2007): 278, doi:10.1037/0003-066X.62.4.271. 